\title{
The Influence of $\mathrm{Mg}(\mathrm{II})$ and $\mathrm{Ca}(\mathrm{II})$ Ions on Rutin Autoxidation in Weakly Alkaline Aqueous Solutions
}

\author{
Slavoljub C. Živanović ${ }^{1}$, Ružica S. Nikolić ${ }^{2}$, Goran M. Nikolić ${ }^{3}$ \\ ${ }^{1}$ University of Niš, Faculty of Medicine, Research Center for Biomedicine, Niš, Serbia \\ ${ }^{2}$ University of Niš, Faculty of Sciences and Mathematics, Department of Chemistry, Niš, Serbia \\ ${ }^{3}$ University of Niš, Faculty of Medicine, Department of Chemistry, Niš, Serbia
}

\section{SUMMARY}

Rutin (quercetin-3-O-rutinoside) is one of the most abundant bioflavonoids with various biological and pharmacological activities. Considering the ubiquitous presence of $\mathbf{M g}$ (II) and $\mathrm{Ca}$ (II) ions in biological systems we decided to investigate their influence on the autoxidation of rutin in weakly alkaline aqueous solutions. Changes in UV-Vis spectra recorded during the rutin autoxidation in aqueous solution at $\mathrm{pH} 8.4$ revealed that this process was very slow in the absence of metal ions. The presence of $\mathrm{Mg}$ (II) and, especially $\mathrm{Ca}$ (II) ion, increased the transformation rate of rutin. UV-Vis spectra recorded after prolonged autoxidation indicated the formation of humic acidlike products in the presence of $\mathrm{Mg}$ (II) and $\mathrm{Ca}(\mathrm{II})$ ions. Four new compounds formed during the initial stage of rutin autoxidation in the presence of $\mathrm{Mg}$ (II) and $\mathrm{Ca}(\mathrm{II})$ ions were detected by HPLCDAD. Based on the analysis of their DAD UV-Vis spectra and comparison of their retention times with the retention time value for rutin, we concluded that the initial rutin transformation products were formed by the water addition on double bond in ring $C$ and hydroxylation of ring $B$. A very small decrease of the initial rutin concentration (4\%) was observed by HPLC-DAD in the absence of metal ions for the period of $\mathbf{9 0}$ minutes. However, rutin concentration decrease was much larger in the presence of $\mathrm{Mg}$ (II) and $\mathrm{Ca}(\mathrm{II})$ ions (14\% and $24 \%$, respectively). The more pronounced effect of $\mathrm{Ca}$ (II) ion on the rutin autoxidation may be explained by the stronger binding of $\mathrm{Mg}$ (II) ion to rutin and thus greater stabilizing effect on reaction intermediates caused by its higher ionic potential (charge/ionic radius ratio) in comparison to $\mathrm{Ca}(\mathrm{II})$ ion. The results of this study may contribute to the better understanding of interactions of $\mathrm{Mg}$ (II) and $\mathrm{Ca}$ (II) ions with natural phenolic antioxidants which are important for their various biological activities.

Key words: rutin, autoxidation, magnesium, calcium

Corresponding author:

Goran M. Nikolić

e-mail : goranhem@yahoo.com 


\section{INTRODUCTION}

Phenolic compounds are ubiquitous in plants and their dietary intake has many beneficial effects on human health $(1,2)$. Rutin (quercetin-3-O-rutinoside), the glycoside between the flavonol quercetin and disaccharide rutinose ( $\alpha$-L-rhamnopyranosyl- $(1 \rightarrow 6)-\beta$ D-glucopyranose) (Figure 1) is one of the most abundant bioflavonoids with various biological and pharmacological activities $(2,3)$.

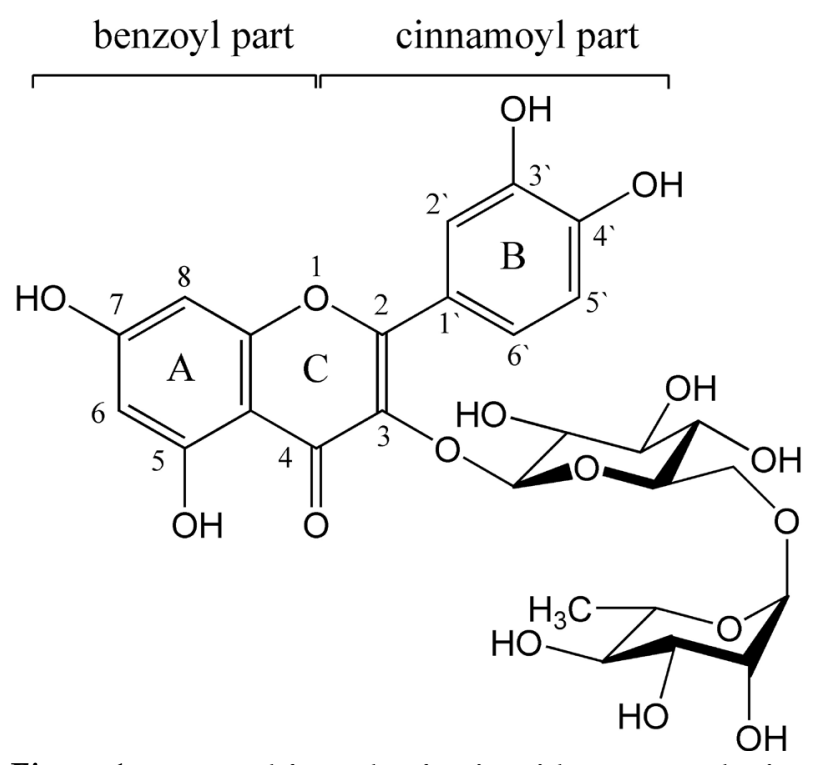

Figure 1: Structural formula of rutin with atom numbering and labeling of structural units responsible for the main absorption bands in UV-Vis spectra

Oxidation or/and autoxidation of natural phenolic compounds may have profound influence on their biological activity and stability of certain types of foods (4). Compounds having two or three vicinal hydroxyl groups on the same benzene ring are especially susceptible to autoxidation, and it was found that this process is mainly influenced by the $\mathrm{pH}$ value (4) and the presence of transition metal ions like Mn(II), $\mathrm{Fe}(\mathrm{II})$, and $\mathrm{Cu}(\mathrm{II})(5,6)$ which are redox active and strongly enhance the autoxidation process. However, the influence of $\mathrm{Mg}$ (II) and $\mathrm{Ca}$ (II) ions on the autoxidation of natural phenolic compounds was studied less frequently $(5,7)$, although these two ions are far more abundant in living organisms than transition metal ions and have a wide variety of important biological functions (8).

There are literature data on the enzymatic (9-12), chemical (11, 13-15), and electrochemical $(16,17)$ oxidation of rutin, but its autoxidation was not studied in detail except in the study of the effect of thermal processing on rutin and quercetin in aqueous solutions (18). Considering the biological importance of both rutin and $\mathrm{Mg}$ (II) and $\mathrm{Ca}$ (II) ions we found it important to study the influence of $\mathrm{Mg}$ (II) and $\mathrm{Ca}$ (II) ions on the rutin autoxidation in a weakly alkaline aqueous solution as a model system.

\section{MATERIAL AND METHODS}

All the chemicals used in this study were of analytical (p.a.) grade, except acetonitrile (ACN) which was of HPLC grade quality. Rutin was purchased from Sigma Aldrich (Germany) and trifluoroacetic acid (TFA) was purchased from Merck (Germany). Deionized water was obtained by using TKA Smart2Pure water purification system (Thermo Scientific, Germany).

Working solutions of rutin $\left(0.5 \mathrm{mmol} \mathrm{dm} \mathrm{dm}^{-3}\right)$ were prepared just before the use by dissolving exactly weighted amount of rutin in deionized water. Autoxidation of rutin was initiated by mixing equal volumes of rutin solution and Tris buffer $(100 \mathrm{mmol}$ $\mathrm{dm}^{-3}, \mathrm{pH}$ 8.4) without salt addition or with either $\mathrm{MgCl}_{2}$ of $\mathrm{CaCl}_{2}$ addition $\left(0.2 \mathrm{~mol} \mathrm{dm}^{-3}\right)$. Autoxidizing solutions were kept at room temperature $\left(22 \pm 1^{\circ} \mathrm{C}\right)$ exposed to air during experiments.

An Evolution 60 UV-Vis scanning spectrophotometer (Thermo Scientific, USA) with $1.0 \mathrm{~cm}$ quartz cells was employed for spectrophotometric measurements. UV-Vis spectra were recorded immediately after mixing rutin and Tris buffer solutions and at regular time intervals of 15 minutes for the next 120 minutes. After that, prolonged autoxidation of rutin was followed by recording UV-Vis spectra at various time intervals up to 24 hours.

An Agilent Technologies 1200 Series system equipped with a vacuum degasser, binary pump, temperature controlled column chamber, autosampler, and a diode-array detector (DAD) was employed for HPLC analyses. Separation was achieved by using Purospher STAR RP-18e column $(150 \times 4.6 \mathrm{~mm}, 5 \mu \mathrm{m}$, Merck, Germany) at $30^{\circ} \mathrm{C}$. Gradient elution was employed with $0.1 \%$ aqueous trifluoroacetic acid (mobile phase A) and acetonitrile (mobile phase B). The gradient of B was established as follows: $0-12 \mathrm{~min}$ from $10 \%$ to $40 \%$; $12-15$ min from $40 \%$ to $80 \%$; $15-16$ min holding $80 \%$, and $16-20 \mathrm{~min}$ from $80 \%$ to $10 \%$. The sample injection volume was $10 \mu \mathrm{L}$ and the mobile phase flow rate was $0.5 \mathrm{~mL} / \mathrm{min}$. The chromatograms were recorded at a 
detection wavelength of $254 \mathrm{~nm}$ (typical for benzoic acid and related compounds).

\section{RESULTS AND DISCUSSION}

UV-Vis spectra recorded immediately after mixing rutin solution with Tris buffer in the absence of metal ions and in the presence of $\mathrm{Mg}$ (II) and $\mathrm{Ca}$ (II) ions are shown in Figure 2.

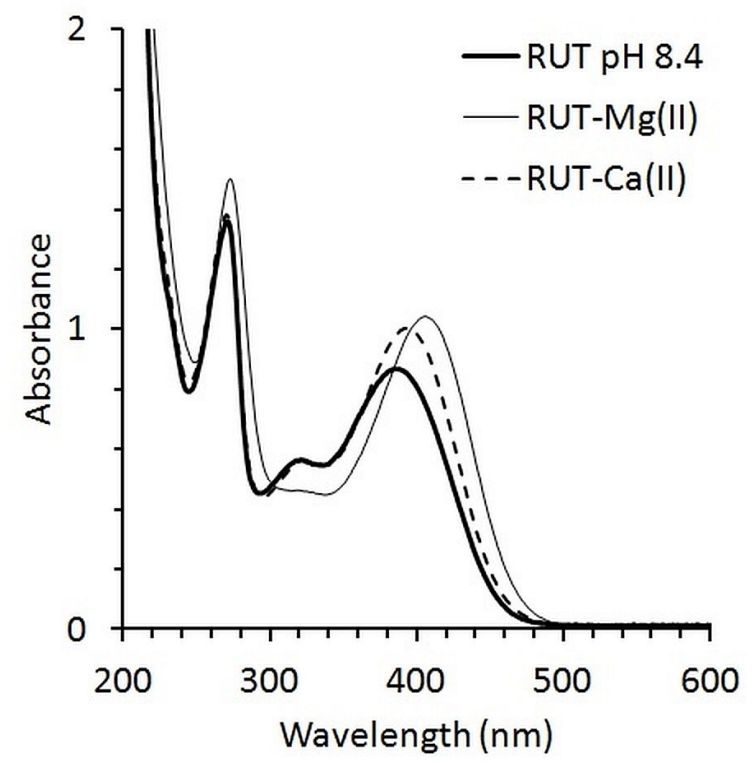

Figure 2: UV-Vis spectra of rutin recorded immediately after mixing of rutin solution with Tris buffer $\mathrm{pH} 8.4$ in the absence of metal ions and in the presence of $\mathrm{Mg}(\mathrm{II})$ and $\mathrm{Ca}(\mathrm{II})$ ions

Two absorption bands characteristic for flavonoids, the benzoyl band in the $240-280 \mathrm{~nm}$ range and the cinnamoyl band in the $320-385 \mathrm{~nm}$ range (19) , appear in the spectra shown in Figure 2. However, at $\mathrm{pH}$ 8.4 in the absence of metal ions absorption maxima of these bands shifted to higher wavelengths (271 and 385 $\mathrm{nm}$ ) in comparison to rutin in acidic solutions (256 and $356 \mathrm{~nm}$ at $\mathrm{pH}$ 3). This bathochromic shift of absorption bands was caused by the partial deprotonation of rutin molecule with increasing $\mathrm{pH}$ value of solution as in the case of similar flavonoid molecules (20). Complexation of flavonoids with metal ion causes further bathochromic shift of characteristic absorption bands (19), and in the presence of $\mathrm{Mg}$ (II) and $\mathrm{Ca}(\mathrm{II})$ ions absorption maximum of the cinnamoyl band shifted to $406 \mathrm{~nm}$ and $395 \mathrm{~nm}$, respectively, while there was almost no shift of the benzoyl band. As in the case of quercetin complexation with $\mathrm{Mg}$ (II) and $\mathrm{Ca}$ (II) ions (21), larger bathochromic shift was caused by the presence of $\mathrm{Mg}(\mathrm{II})$ ion which may be explained by its higher ionic potential (charge/ionic radius ratio) in comparison to $\mathrm{Ca}$ (II) ion.

UV-Vis spectra recorded at regular 15 minutes time intervals for the period of 120 minutes for mixtures of rutin solution and Tris buffer in the absence of metal ions and in the presence of $\mathrm{Mg}$ (II) and $\mathrm{Ca}(\mathrm{II})$ ions are shown in Figure 3.

Very small, practically negligible changes occurred in the UV-Vis spectra during the autoxidation of rutin in aqueous solution at $\mathrm{pH} 8.4$ in the absence of metal ions for the period of 120 minutes. On the other side, in the presence of $\mathrm{Mg}$ (II), and especially $\mathrm{Ca}$ (II) ion, notable changes occurred in the UV-Vis spectra. There was absorbance decrease for the two main absorption bands but also small absorbance increase at some wavelengths (indicated by the arrows in Figure 3). In the rutin-Ca(II) system, three well defined isobestic points appeared at 262, 278, and $306 \mathrm{~nm}$, thus indicating the existence of two absorbing species in equili-

brium under these conditions. Changes in UVVis spectra observed during the autoxidation of rutin in the presence of $\mathrm{Mg}$ (II) and $\mathrm{Ca}$ (II) ions were quite different in comparison to the changes occurring during the irradiation and thermolysis of rutin where the overall decrease of absorption at all wavelengths indicated the formation of degradation products with no chromophore structures (22).

UV-Vis spectra recorded after 20 hours of rutin autoxidation in the absence and presence of metal ions are shown in Figure 4.

UV-Vis spectrum recorded after 20 hours of rutin autoxidation in the absence of metal ions at $\mathrm{pH}$ 8.4 was almost identical to its initial UV-Vis spectrum with only a small decrease of absorbance for the two main absorption bands. In the case of rutin autoxidation in the presence of $\mathrm{Mg}$ (II) and $\mathrm{Ca}$ (II) ions, UVVis spectra recorded after 20 hours of autoxidation have much different appearance in comparison to the initial spectra and resemble the UV-Vis spectra of products obtained during the oxidation of rutin by horseradish peroxidase (10) and spectra of humic acids (natural compounds formed by the polymerization of simple phenolic compounds) (23).

Further investigation of the rutin autoxidation process was performed by HPLC-DAD. Chromatograms were recorded at regular 30-minute intervals from the start of autoxidation, and beside the decrease of rutin chromatographic peak intensity no significant new compounds were observed after 60 minutes of 

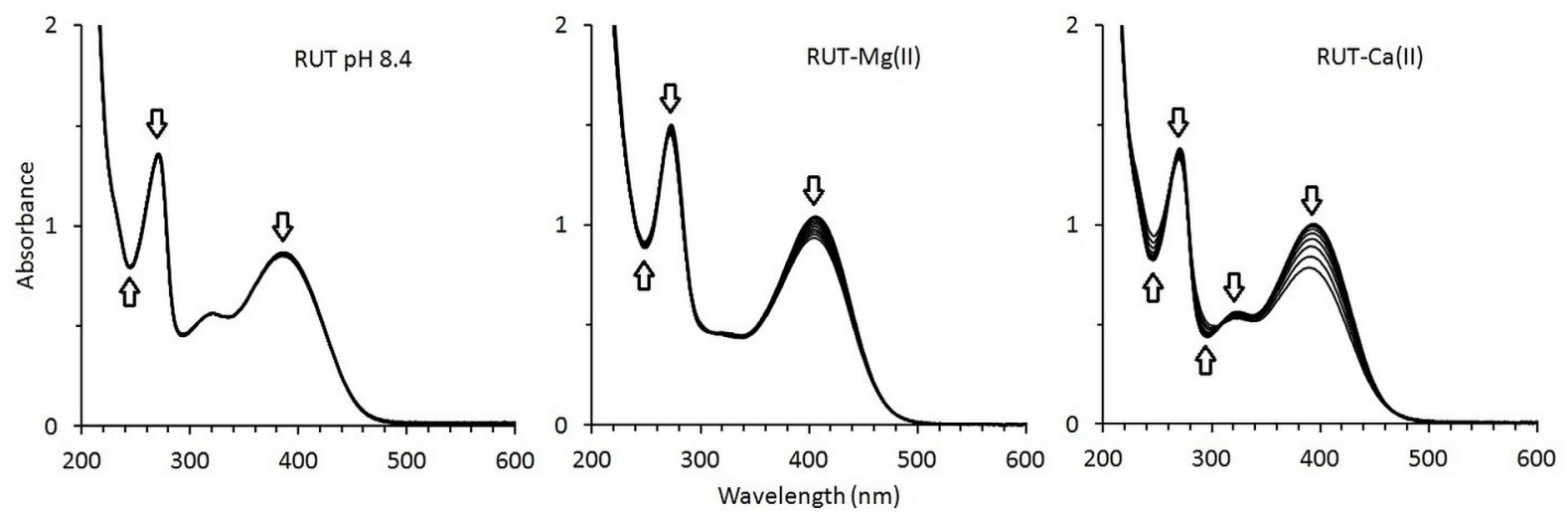

Figure 3: UV-Vis spectra recorded during the rutin autoxidation at regular 15 minute intervals for the period of 120 minutes. Arrows indicate changes of absorbance at specific wavelengths

autoxidation. Chromatograms recorded after $90 \mathrm{mi}-$ nutes of rutin autoxidation in the absence and presence of metal ions are shown in Figure 5.

In the chromatogram recorded after 90 minutes of rutin autoxidation in aqueous solution at $\mathrm{pH} 8.4$ in the absence of metal ions, only the peak originating

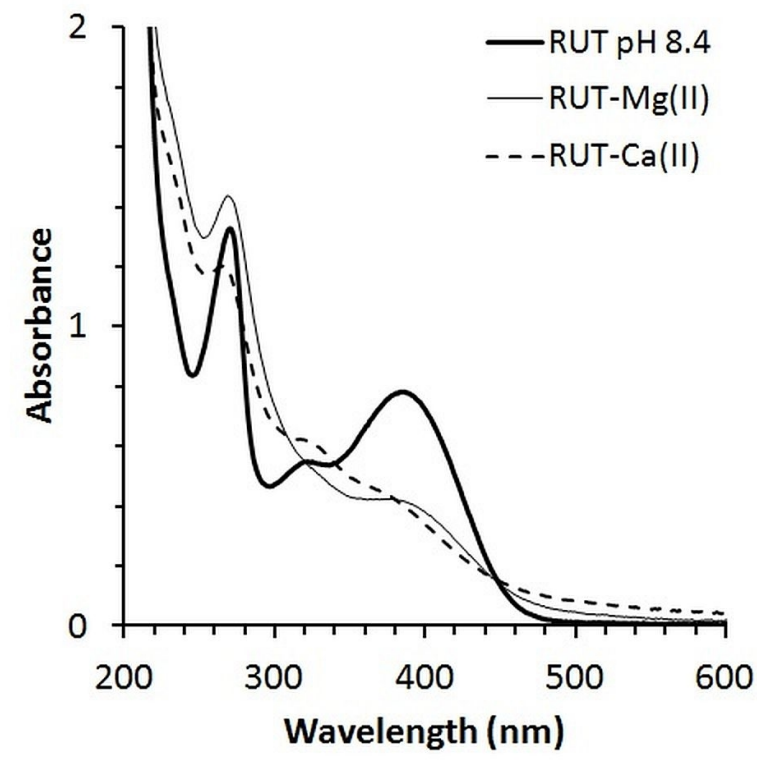

Figure 4 :UV-Vis spectra recorded after 20 hours of rutin autoxidation at $\mathrm{pH} 8.4$ in the absence of metal ions and in the presence of $\mathrm{Mg}(\mathrm{II})$ and $\mathrm{Ca}(\mathrm{II})$ ions

from rutin at retention time (RT) of 12.3 minutes can be observed. The peak originating from rutin is still prevailing in chromatograms recorded after 90 minutes of rutin autoxidation in the presence of $\mathrm{Mg}$ (II) and $\mathrm{Ca}$ (II) ions, but four minor peaks at RT 9.8, 10.1, 10.5, and 10.8 minutes originating from the products of rutin transformations in these systems appeared. Smaller RT values in comparison to rutin indicate that these new compounds are more polar because nonpolar $\mathrm{C} 18$ co-

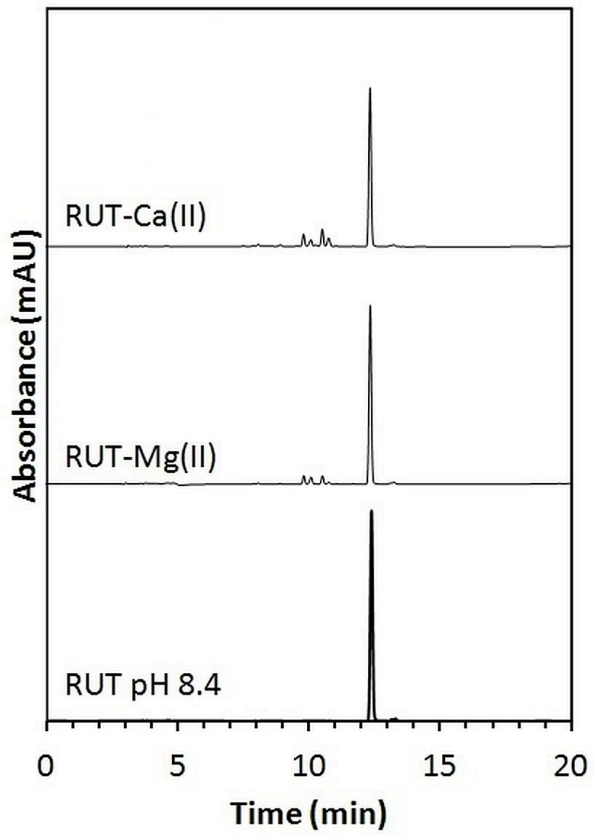

Figure 5: Chromatograms recorded after 90 minutes of rutin autoxidation at $\mathrm{pH} 8.4$ in the absence of metal ions and in the presence of $\mathrm{Mg}$ (II) and $\mathrm{Ca}(\mathrm{II})$ ions. Detection wavelength was set at $254 \mathrm{~nm}$

lumn was used for chromatographic separation. DAD UV-Vis spectra extracted from the chroma-tographic peaks of these new compounds are identical for both RUT-Mg(II) and RUT-Ca(II) systems and very similar to the DAD UV-Vis spectrum of rutin. Beside this, DAD UV-Vis spectra of compounds with RT values of 9.8 and 10.5 minutes are practically identical (absorbance ratios of their spectra are nearly constant in the wavelength range from 210 to $400 \mathrm{~nm}$ ). Plausible explanation for the identical UV-Vis spectra of two compounds with different RT values may be that they are diastereoisomers formed by the addition of water to the double bond between $\mathrm{C} 2$ and $\mathrm{C} 3$ in the ring $\mathrm{C}$ of 
rutin (Figure 1). The possibility of solvent addition on this double bond during the oxidation by DPPH or autoxidation of quercetin and its derivatives (including rutin) in protic solvents has been already reported in the literature (24). For the other two minor compounds obtained during the autoxidation of rutin in the presence of $\mathrm{Mg}$ (II) and $\mathrm{Ca}$ (II) ions appearing in chromatograms at RT 10.1 and 10.8 minutes, we tentatively propose the structures obtained by the hydroxylation of ring $B$ of rutin. This assumption is<smiles>[R2]c1c(-c2ccc(O)c(O)c2)oc2cc(O)cc(O)c2c1=O</smiles>

Figure 6: Schematic presentation of initial rutin transformations during its autoxidation at $\mathrm{pH} 8.4$ in the presence of $\mathrm{Mg}(\mathrm{II})$ and $\mathrm{Ca}(\mathrm{II})$ ions ( $\mathrm{R}$ = rutinoside).

based on the fact that the possibility of B ring hydroxylation in alkaline solutions is well documented for some flavonols with two ortho hydroxyl groups on this ring (25). Also, as already stated, smaller RT values for these compounds in comparison to rutin (RT 12.3 minutes) indicate that they are more polar. However, RT value differences are not so large as to indicate some big structural changes like ring cleavage with very polar carboxylic group formation.

Possible transformations of rutin during the initial phase of autoxidation in weakly alkaline aqueous solution in the presence of $\mathrm{Mg}$ (II) and $\mathrm{Ca}(\mathrm{II})$ ions are schematically presented in Figure 6 .

Measurements of rutin HPLC peak area at various time intervals allowed the estimation of rutin concentration change during autoxidation in systems studied in this work, and these results are shown in Figure 7.

Rutin concentration decreased only about $4 \%$ for 90 minutes during the autoxidation at $\mathrm{pH} 8.4$ in the absence of metal ions, but the presence of $\mathrm{Mg}(\mathrm{II})$, and especially $\mathrm{Ca}(\mathrm{II})$ ion, significantly increased its consumption rate. About $14 \%$ and $24 \%$ decrease of initial rutin concentration was observed during its autoxidation in the presence of $\mathrm{Mg}$ (II) and $\mathrm{Ca}$ (II) ions, respectively, for the period of 90 minutes. The increased transformation

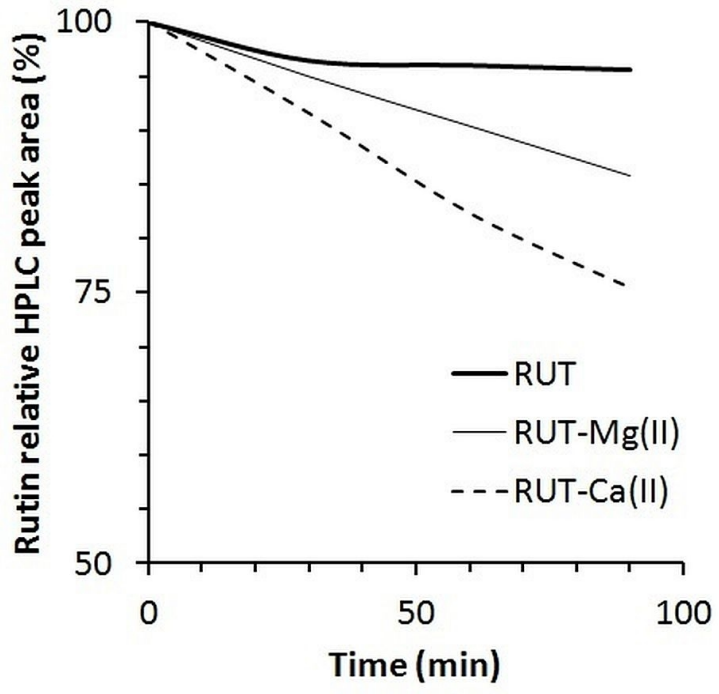

Figure 7: Relative change of HPLC peak area of rutin with time during its autoxidation at $\mathrm{pH} 8.4$ in the absence of metal ions and in the presence of $\mathrm{Mg}$ (II) and $\mathrm{Ca}(\mathrm{II})$ ions. 
rate of rutin in the presence of $\mathrm{Mg}$ (II) and $\mathrm{Ca}$ (II) ions may be explained by the increased dissociation constants of hydroxyl groups of phenolic compounds in the presence of divalent diamagnetic metal ions (26), which promotes further transformations. However, although both metal ions increased the rutin transformation rate, the effect of $\mathrm{Ca}$ (II) ion was more pronounced probably because of tighter binding of $\mathrm{Mg}$ (II) ion to rutin and greater stabilizing effect on reaction intermediates.

\section{CONCLUSION}

UV-Vis spectrophotometry and HPLC-DAD have been applied for studying the influence of $\mathrm{Mg}$ (II) and $\mathrm{Ca}(\mathrm{II})$ ions on the autoxidation of rutin in weakly alkaline aqueous solutions. Changes in UV-Vis spectra recorded during the rutin autoxidation in aqueous solution at $\mathrm{pH} 8.4$ revealed that this process was very slow in the absence of metal ions. The presence of $\mathrm{Mg}$ (II) and especially $\mathrm{Ca}(\mathrm{II})$ ion, increased the transformation rate of rutin and this may be explained by the increased dissociation of phenolic hydroxyl groups which promotes further transformations. UVVis spectra recorded after prolonged autoxidation (20 hours) indicated the formation of humic acid-like products in the presence of $\mathrm{Mg}$ (II) and $\mathrm{Ca}$ (II) ions. HPLC-DAD enabled the detection of four new compounds formed during the rutin autoxidation in the presence of $\mathrm{Mg}$ (II) and $\mathrm{Ca}(\mathrm{II})$ ions. Based on the analysis of DAD UV-Vis spectra of these newly formed compounds and comparison of their retenti- on times with the retention time value for rutin, we concluded that the initial rutin transformation products were obtained by the water addition on double bond in ring $\mathrm{C}$ and hydroxylation of ring $\mathrm{B}$. HPLC-DAD also enabled the quantitative estimation of rutin consumption during autoxidation in the absence of metal ions and in the presence of $\mathrm{Mg}$ (II) and $\mathrm{Ca}(\mathrm{II})$ ions. Very small decrease in the initial rutin concentration ( $4 \%$ ) was detected in the absence of metal ions for the period of 90 minutes; however, rutin concentration decrease was much larger in the presence of $\mathrm{Mg}(\mathrm{II})$ and $\mathrm{Ca}(\mathrm{II})$ ions (14\% and $24 \%$, respectively). The more pronounced effect of $\mathrm{Ca}$ (II) ion on the rutin autoxidation may be explained by the stronger binding of $\mathrm{Mg}$ (II) ion to rutin and thus greater stabilizing effect on reaction intermediates caused by its higher ionic potential (charge/ionic radius ratio) in comparison to $\mathrm{Ca}(\mathrm{II})$ ion.

The results of this study may contribute to the better understanding of interactions of $\mathrm{Mg}$ (II) and $\mathrm{Ca}$ (II) ions with natural phenolic antioxidants which are important for their various biological activities, and also for the optimization of conditions for processing and storage of certain types of foods.

\section{Acknowledgment}

This work was financially supported by the Ministry of Education and Science of the Republic of Serbia under the project no. 172044. 


\section{References}

1. Vauzour D, Rodriguez-Mateos A, Corona G, Oruna-Concha MJ, Spencer JPE et al. Polyphenols and human health: Prevention of disease and mechanisms of action. Nutrients 2010; 2: 1106-1131.

http://dx.doi.org/10.3390/nu2111106

2. Crozier A, Jaganath IB, Clifford MN. Dietary phenolics: chemistry, bioavailability and effects on health. Nat Prod Rep 2009; 26: 1001-1043.

http://dx.doi.org/10.1039/b802662a

3. Al-Dhabi NA, Arasu MV, Park CH, Park SU. An up-to-date review of rutin and its biological and pharmacological activities. EXCLI J 2015; 14: 5963.

\section{http://dx.doi.org/10.17179/excli2014-663}

4. Friedman M, Jürgens HS. Effect of $\mathrm{pH}$ on the stability of plant phenolic compounds. J Agric Food Chem 2000; 48: 2101-2110.

http://dx.doi.org/10.1021/jf990489j

5. García P, Romero C, Brenes M, Garrido A. Effect of metal cations on the chemical oxidation of olive o-diphenols in model systems. J Agric Food Chem 1996; 44: 2101-2105.

http://dx.doi.org/10.1021/jf9503265

6. Nkhili E, Loonis M, Mihai S, El Hajji H, Dangles O et al.. Reactivity of food phenols with iron and copper ions: binding, dioxygen activation and oxidation mechanisms. Food Funct 2014; 5: 11861202.

http://dx.doi.org/10.1039/c4fo00007b

7. Nikolić GM, Veselinović AM, Nikolić RS, Mitić SS. Spectroscopic study of $\mathrm{Mg}$ (II) ion influence on the autoxidation of gallic acid in weakly alkaline aqueous solutions. Russ J Phys Chem A 2011; 85: 2270-2273.

http://dx.doi.org/10.1134/S0036024411130176

8. Crichton RR. An overview of the roles of metals in biological systems. In: Crichton RR, Louro RO (eds), Practical approaches to biological inorganic chemistry. Elsevier B.V., Amsterdam, 2013: 1-22.

9. Loth H. Über die oxydation des rutins durch peroxydase. Arch Pharm 1961; 294: 419-427.

http://dx.doi.org/10.1002/ardp.19612940707

10. Takahama U. Spectrophotometric study on the oxidation of rutin by horseradish peroxidase and characteristics of the oxidized products. Biochim Biophys Acta 1986; 882: 445-451.

http://dx.doi.org/10.1016/0304-4165(86)90269-2

11. Makris DP, Rossiter JT. An investigation on structural aspects influencing product formation in enzymic and chemical oxidation of quercetin and related flavonols. Food Chem 2002; 77: 177185.

http://dx.doi.org/10.1016/S0308-8146(01)00333-8

12. Savic S, Vojinovic K, Milenkovic S, Smelcerovic A, Lamshoeft M, Petronijevic Z et al.. Enzymatic oxidation of rutin by horseradish peroxidase: Kinetic mechanism and identification of a dimeric product by LC-Orbitrap mass spectrometry. Food Chem 2013; 141: 4194-4199. http://dx.doi.org/10.1016/j.foodchem.2013.07.010

13. Tournaire C, Hocquaux M, Beck I, Oliveros E, Maurette M-T et al. Activité anti-oxydante de flavonoïdes. Réactivité avec le superoxyde de 
potassium en phase héetérogenè. Tetrahedron 1994; 50: 9303-6314.

http://dx.doi.org/10.1016/S0040-4020(01)85507-1

14. Sung J, Huang K-S, Lai T-J et al. Oxidation of catechin and rutin by pentaammineruthenium(III) complexes. Inorg Chem 2008; 47: 11361-11366.

http://dx.doi.org/10.1021/ic801419k

15. Lin L-M, Wu H-Y, Li W-S et al. Kinetic studies of the oxidation of quercetin, rutin and taxifolin in the basic medium by (ethylenediaminetetraacetato) cobalt(III) complex. Inorg Chem Commun 2010; 13: 633-635.

http://dx.doi.org/10.1016/j.inoche.2010.03.006

16. Ghica E-M, Brett AMO. Electrochemical oxidation of rutin. Electroanalysis 2005; 17: 313318.

\section{http://dx.doi.org/10.1002/elan.200403100}

17. He J-B, Wang Y, Deng N, Lin X-Q. Study of the adsorption and oxidation of antioxidant rutin by cyclic voltammetry-voltabsorptometry. Bioelectrochemistry 2007; 71: 157-163.

http://dx.doi.org/10.1016/j.bioelechem.2007.03.003

18. Buchner N, Krubein A, Rohn S, Kroh LW. Effect of thermal processing on the flavonols rutin and quercetin. Rapid Commun Mass Spectrom 2006; 20: 3229-3235.

http://dx.doi.org/10.1002/rcm.2720

19. Kasprzak MM, Erxleben A, Ochocki J. Properties and applications of flavonoid metal complexes. RSC Adv 2015; 5: 45853-45877.

http://dx.doi.org/10.1039/c5ra05069c

20. Jurasekova Z, Domingo C, Garcia-Ramos JV, Sanchez-Cortes $\mathrm{S}$. Effect of $\mathrm{pH}$ on the chemical modification of quercetin and structurally related flavonoids characterized by optical (UV-visible and Raman) spectroscopy. Phys Chem Chem Phys 2014; 16: 12802-12811.

http://dx.doi.org/10.1039/c4cp00864b

21. Erdogan G, Karadg R. Quercetin $\left(3,3^{\prime}, 4^{\prime}, 5,7-\right.$ pentahydroxyflavone) complexes with calcium(II) and magnesium(II), its potentiometric and spectrophotometric studies. Rev Anal Chem 2005; 24: 9-23.

http://dx.doi.org/10.1515/REVAC.2005.24.1.9

22. Paczkowska M, Lewandowska K, Bednarski W et al. Application of spectroscopic methods for the identification (FT-IR, Raman spectroscopy) and determination (UV, EPR) of quercetin-3-Orutinoside. Experimental and DFT based approach. Spectrochim Acta A 2015; 140: 132-139. http://dx.doi.org/10.1016/j.saa.2014.12.050

23. Veselinović AM, Bojić Alj, Purenović MM et al. Ispitivanje uticaja parametara $\mathrm{UV} / \mathrm{H} 2 \mathrm{O} 2$ procesa na degradaciju huminskih kiselina. Hem ind 2010; 64: 265-273.

http://dx.doi.org/10.2298/HEMIND100315036V

24. Dangles O, Fargeix G, Dufour C. One-electron oxidation of quercetin and quercetin derivatives in protic and non protic media. J Chem Soc Perkin Trans 2 1999; 1999: 1387-1395.

http://dx.doi.org/10.1039/A901460H

25. Cotelle N, Bernier J-L, Catteau J-P, Pommery J, Wallet J-C, Gaydou EM et. Antioxidant properties of hydroxy-flavones. Free Radic Biol Med 1996; 20: 35-43. http://dx.doi.org/10.1016/0891-5849(95)02014-4

26. Lebedev AV, Ivanova MV, Timoshin AA, Ruuge EK. Effect of group II metal cations on catecholate oxidation. ChemPhysChem 2007; 8: 1863-1869.

http://dx.doi.org/10.1002/cphc.200700296 


\title{
Uticaj Mg(II) i Ca(II) jona na autooksidaciju rutina slabo baznim vodenim rastvorima
}

\author{
Slavoljub C. Živanović ${ }^{1}$, Ružica S. Nikolić2 ${ }^{\text {, Goran M. Nikolić }}{ }^{3}$ \\ ${ }^{1}$ Univerzitet u Nišu, Medicinski fakultet, Naučnoistraživački centar za biomedicinu, Niš, Srbija \\ 2 Univerzitet u Nišu, Prirodno-matematički fakultet, Departman za Hemiju, Niš, Srbija \\ ${ }^{3}$ Univerzitet u Nišu, Medicinski fakultet, Katedra Hemija, Niš, Srbija
}

\section{SAŽETAK}

Rutin (kvercetin-3-O-rutinozid) je jedan od najzastupljenijih bioflavonoida sa različitim biološkim i farmakološkim aktivnostima. Imajući u vidu univerzalno prisustvo $\mathbf{M g}$ (II) i Ca(II) jona u biološkim sistemima, odlučili smo da ispitamo njihov uticaj na autooksidaciju rutina u slabo baznim vodenim rastvorima.

Praćenjem promena $\mathrm{u}$ UV-Vis spektrima koji su snimani $\mathbf{u}$ toku autooksidacije rutina $\mathbf{u}$ vodenom rastvoru na $\mathrm{pH} 8,4$ utvrđeno je da je ovaj proces veoma spor u odsustvu metalnih jona. Prisustvo $\mathrm{Mg}$ (II) i naročito $\mathrm{Ca}(\mathrm{II})$ jona povećelo je brzinu transformacije rutina. UV-Vis spektri, snimljeni nakon produžene autooksidacije rutina, ukazali su na formiranje proizvoda sličnih huminskim kiselinama $u$ prisustvu Mg(II) i Ca(II) jona. Četiri nova jedinjenja nastala u početnoj fazi autooksidacije rutina u prisustvu Mg(II) i Ca(II) jona detektovana su pomoću HPLC-DAD. Na osnovu analize njihovih DAD UV-Vis spektara $i$ poređenja njihovih retencionih vremena sa retencionim vremenom za rutin zaključeno je da su početni proizvodi transformacije rutina nastali adicijom vode na dvostruku vezu $u$ prstenu C i hidroksilacijom prstena B. Veoma malo smanjenje početne koncentracije rutina (4\%) je uočeno pomoću HPLC-DAD u odsustvu metalnih jona u periodu od 90 minuta, ali je smanjenje koncentracije rutina bilo znatno veće u prisustvu $\mathrm{Mg}$ (II) i Ca(II) jona (14\%, odnosno $24 \%$ ). Izraženiji uticaj Ca(II) jona na autooksidaciju rutina može se objasniti jačim vezivanjem $\mathbf{M g}$ (II) jona za rutin, što doprinosi stabilizaciji reakcionih intermedijera, a uzrokovano je većim jonskim potencijalom (odnos naelektrisanje/jonski radijus) $u$ odnosu na Ca(II) jon.

Rezultati ovog istraživanja mogu da doprinesu boljem razumevanju interakcija $\mathrm{Mg}$ (II) i Ca(II) jona sa prirodnim fenolnim antioksidantima koje su značajne za njihove različite biološke aktivnosti.

Ključne reči: rutin, autooksidacija, magnezijum, kalcijum 